\title{
SENSORY DIFFERENTIATION OF COMMERCIALLY PRODUCED SPAGHETTI
}

\author{
Mladenka V. Pestorić*, Milica M. Pojić, Bojana V. Filipčev, Olivera D. Šimurina, Aleksandra M. \\ Torbica, Elizabet P. Janić Hajnal \\ University of Novi Sad, Institute of Food Technology, 21000 Novi Sad, \\ Bulevar cara Lazara 1, Serbia
}

\author{
${ }^{*}$ Corresponding author: \\ Phone: +381214853782 \\ Fax: +38121450725 \\ E-mail address: mladenka.pestoric@fins.uns.ac.rs
}

\begin{abstract}
This work was focused on the performance of trained and untrained panel in evaluating the texture of nine commercially produced wheat spaghetti. Several sensory methods were applied in order to investigate the performance of different panel groups. In order to avoid the loss of information obtained by non-parametric methods, data were scaled according to contingency tables. This analysis showed that significant differences existed between the two panels for the given products. On the basis of these results, it can be concluded that the used panels cannot be a good alternative to each other in providing sensory texture profiling of commercial spaghetti, except in the case when the properties of spaghetti were evaluated using the control sample.
\end{abstract}

Key words: sensory evaluation, pasta, texture, consumer acceptance, panels' comparison

\section{INTRODUCTION}

Among the quality properties of spaghetti, texture is one of the most important factors affecting pasta quality and consumer acceptance. Dry spaghetti must appeal to the consumer at the point of purchase, whilst cooked spaghetti must meet consumer criteria, such as smooth surface, firmness, etc. (Cole, 1991; Tang et al., 1999; Lee et al., 2002; Sissons et al., 2005). The sensory evaluation of texture is necessary in the production of spaghetti for many reasons: to describe the sensory properties of products, to improve product quality through the production process and to make comparisons with competitors' products. Furthermore, sensory evaluation is the nearest to consumers' estimation and therefore it allows the evaluation of overall properties of dry and cooked spaghetti. Therefore, it is considered to be the most reliable method (Latreille et al.,
2005). A certain number of studies have been undertaken that involve a comprehensive sensory evaluation of spaghetti texture. Attempts to quantify texture of spaghetti have involved both oral (Voisey et al. 1978a; Kovacs et al., 1997), and non-oral (Voisey et al., 1978b) procedures including visual and tactile evaluations. Various generic descriptive analysis techniques have been used by many researches (Tang et al., 1999; Sözer and Kaya, 2003; Martinez et al., 2007; Sözer et al., 2007) to evaluate textural properties of spaghetti, such as the scoring method (D'Egidio and Nardi, 1996) or/and the method of extensive scoring system (Menger, 1985). Moreover, the method of unstructured line scales was used to record rating of each property (Malcomson, 1991). The International Organization of Standardization (ISO 7340 1985) has de- 
veloped a standard method using trained panellists for evaluating the textural properties of cooked spaghetti based on the use of reference samples and nine point rating scale. Selected assessors or experts are trained to evaluate sensory properties using different scales and for that reason, they are important factors for describing textural quality of different foods (Stone and Sidel, 1998; Szczesniak, 1998; Szczesniak, 2002). Although evaluation of textural properties performed by trained panel is recognized as a key step in the assessment of spaghetti quality, the use of consumer based measurements is sometimes recommended as an equivalent to the experts (Gonzáles et al., 2001). The consistency of results obtained from different sensory groups of assessors is an issue which has been frequently addressed, particularly within the industry. Previously, many authors compared results from experts and instructed consumer panellists and some of them agreed (Moskowitz, 1996) that both groups showed similar types of results on similar properties, while others recommended the superior capability of experts (Cardello et al., 1982; Guerrero et al., 1997; Hough, 1998).

On the other hand, during the past decade, many multivariate techniques were successfully used in food research to study the interrelationship between multiple data sets and to extract the principal information from massive and complex data (Popper et al., 1988). However, nonparametric data scaled by using contingency tables have not been used to investtigate differentiation of commercial spaghetti evaluated by different panel groups. By using contingency tables for non-parametric data the objectives of this paper were to:

- determine the performance of the panel in relation to the evaluated properties,

- identify differences between the panels,

- determine whether there is a clearly defined boundary between the panels in relation to the observed properties obtained by different sensory methods.

\section{MATERIAL AND METHODS}

\section{Samples}

Nine samples of commercial wheat spaghetti were purchased in a local food store. The samples were labelled as sample 1 to sample 9. The samples 1-7 were made from durum wheat semolina, whilst samples 8-9 were made from soft wheat farina.

\section{Sensory evaluation}

Sensory evaluation was performed by different panel groups: trained and untrained. Within the trained panel there were 5 experts (three female and two male), age between 35 and 45 years. They belong to the sensory panel in charge of assuring the sensory quality control for the Institute of Food Technology (Novi Sad, Serbia), holding weekly sessions for the purpose according to ISO 8586-2 (1994).

An untrained panel consisted of 42 members of staff ( 29 female and 13 male) from the pasta factory Žitko (Bačka Topola, Serbia). Although previously untrained for the specific task, the staff had a formal training in sensory evaluation and therefore, they were accustomed to the basic concept of the evaluation.

Sensory properties of dry and cooked spaghetti were evaluated by the 5-point category scale with end-points labelled from 1 to 5 as shown in Table 1 (Pestorić et al., 2012).

Both panels evaluated the coded cooked pasta samples by comparison with the control sample for firmness, chewiness, adhesiveness and surface adhesiveness, using $15 \mathrm{~cm}$ instructed line scale (anchored at $1.5 \mathrm{~cm}$ and $13.5 \mathrm{~cm}$ with slight to very, respectively (Kovacs et al. 1997). After evaluation, in order to enable comparison of obtained data and data analysis, the scale was divided into 5 parts (3 $\mathrm{cm}$ each) that corresponded to the certain level of quality.

Furthermore, assessors were asked to evaluate the degree of similarity of the samples to the control one regarding firmness, chewiness, adhesiveness, surface adhesiveness of cooked spaghetti, as well as the overall spaghetti quality. 
Table 1.

Scoring method for dry and cooked spaghetti

DRY SPAGHETTI

Visual evaluation

\begin{tabular}{|c|c|c|}
\hline Shape & Surface appearance & Cross-section appearance \\
\hline $\begin{array}{l}\text { 5- Appropriate (uniform) with no } \\
\text { damage } \\
4 \text { - Insignificant deviation of shape } \\
3 \text { - Noticeable deficiencies } \\
2 \text { - Clearly noticeable deficiencies } \\
1 \text { - Highly noticeable deficiencies }\end{array}$ & $\begin{array}{l}\text { 5- Uncracked } \\
4 \text { - Insignificantly cracked } \\
3 \text { - Partly cracked } \\
2 \text { - Significantly cracked } \\
1 \text { - Marbled }\end{array}$ & $\begin{array}{l}5 \text { - Completely vitreous } \\
4 \text { - Vitreous } \\
3 \text { - Partly vitreous } \\
2 \text { - Partly mealy } \\
1 \text { - Mealy }\end{array}$ \\
\hline \multicolumn{3}{|l|}{ Palpatory evaluation } \\
\hline Surface property & \multicolumn{2}{|c|}{ Fracturability } \\
\hline $\begin{array}{l}5 \text { - Extremely smooth } \\
4 \text { - Smooth } \\
3 \text { - Slightly rough } \\
2 \text { - Pretty rough } \\
1 \text { - Rough }\end{array}$ & \multicolumn{2}{|c|}{$\begin{array}{l}5 \text { - Excellent resistance to fracture } \\
4 \text { - Very good resistance to fracture } \\
3 \text { - Good resistance to fracture } \\
2 \text { - Poor resistance to fracture } \\
\text { 1- Extremely poor resistance to fracture }\end{array}$} \\
\hline \multicolumn{3}{|l|}{ COOKED SPAGHETTI } \\
\hline \multicolumn{3}{|l|}{ Visual evaluation } \\
\hline \multicolumn{3}{|l|}{ Surface appearance } \\
\hline \multicolumn{3}{|l|}{$\begin{array}{l}5 \text { - Not slimy } \\
4 \text { - Insignificantly slimy } \\
3 \text { - Slightly slimy } \\
2 \text { - Slimy } \\
1 \text { - Extremely slimy }\end{array}$} \\
\hline \multicolumn{3}{|l|}{ Palpatory evaluation } \\
\hline Surface adhesiveness & \multicolumn{2}{|c|}{ Elasticity } \\
\hline $\begin{array}{l}5 \text { - Not sticky } \\
4 \text { - Insignificantly sticky } \\
3 \text { - Slightly sticky } \\
2 \text { - Sticky } \\
1 \text { - Extremely sticky }\end{array}$ & \multicolumn{2}{|c|}{$\begin{array}{l}5 \text { - Excellent elasticity } \\
4-\text { Very good elasticity } \\
3 \text { - Good elasticity } \\
2 \text { - Poor elasticity } \\
1 \text { - Extremely poor elasticity }\end{array}$} \\
\hline \multicolumn{3}{|l|}{ Gustatory evaluation } \\
\hline Firmness & Chewiness & Adhesiveness \\
\hline $\begin{array}{l}5 \text { - Excellent firmness (al dente) } \\
4 \text { - Very good firmness } \\
3 \text { - Good firmness } \\
2 \text { - Poor firmness } \\
1 \text { - Extremely poor firmness }\end{array}$ & $\begin{array}{l}5 \text { - Excellent chewiness (al dente) } \\
4 \text { - Very good chewiness } \\
3 \text {-Good chewiness } \\
2 \text { - Poor chewiness } \\
1 \text { - Extremely poor chewiness }\end{array}$ & $\begin{array}{l}5 \text { - Not sticky } \\
4 \text { - Insignificantly sticky } \\
3 \text { - Slightly sticky } \\
2 \text { - Sticky } \\
1 \text { - Extremely sticky }\end{array}$ \\
\hline
\end{tabular}

The centre of the scale corresponded to the case when the intensity of sample property was the same as the property of the control sample (commercial sample spaghetti which was endorsed by consensus of sufficient intensity on the score line for the individual characteristic textural properties, which are included in the evaluation of textural quality pasta). The left side of the scale corresponded to lower assessment - "worse", while the right side corresponded to better assessment "better" of each property.

In order to obtain the overall quality of spaghetti samples assessors used the hedonic scale with 5 quality grades: 1 - extremely dislike 2 - moderately dislike 3 - neither like nor dislike, 4 - moderately like, 5 - extremely like.

The anchored reference standards, terminology definitions and evaluation techniques were agreed upon by the assessors during training and the formal training before evaluation (Szczesniak, 1963; Civille and Szczesniak, 1973; Muñoz, 1985; ISO 11036:1994; Tang et al., 1999).

All samples were presented to each panel in the single sessions. At the start of each session panellists were given a printed response sheet with written instructions for the tests. The order of sample presentation was completely randomized among assessors, identified with three random numbers. Dry spaghetti was presented on 
the plastic plates, while cooked spaghetti was presented in $250-\mathrm{ml}$ sealed thermal plastic cups and served at room temperature within 30 min after cooking. Spaghetti was cooked in boiling distilled water. The optimal cooking time (al dente point) was determined by compressing the spaghetti strand between two transparent plastic plates at different times. It was reached when the white centre of ungelatinized starch had just disappeared according to the approved AACC Method 16-50 cooking time (AACC, 1995). All properties were evaluated visually, palpatory and gustatory under daylight. Drinking water was provided for palate cleansing between each sample.

\section{Statistical evaluation of data}

Statistical analysis comprised the evaluation of spaghetti properties by non-parametric methods according to the frequency of assessments. Non-parametric data were scaled by using contingency tables in order to generate the value for each assessment. Thus, it was enabled to use statistical tests for ratio scales. Generated data were subjected to the Multivariate Analysis of Variance (MANOVA) and Discriminative Analysis. Univariate methods applied included Roy's test, Pearson's contingency coefficient $(\chi)$ and multiple regression coefficient $(R)$. On the basis of discrimination coefficients, the principal properties of spaghetti samples were selected for further analysis. Also, the prediction of homogeneity of assessments was done. Mahalanobis distance indicated the similarity or differences of the panel evaluation in relation to the used sensory method. Statistical analysis of sensory evaluation of panels was conducted using software developed by the Agency "SMARTLINE", Novi Sad (Wilbur, 1984).

\section{RESULTS AND DISCUSSION}

In accordance with the objectives of the research and methodological approach, the differences in panel performance were observed in the five independent statistical subsets:

- Subset $S 1$ - evaluation of the properties of dry spaghetti using the scoring method,
- Subset S2 - evaluation of the properties of cooked spaghetti using the scoring method,

- Subset S3 - evaluation of the properties of cooked spaghetti using the scale method,

- Subset S4 - evaluation of properties of spaghetti using the control sample,

- Subset S5 - evaluation of the overall spaghetti quality using the hedonic scale method.

Applied MANOVA test $(P \leq 0.05)$ indicated that there was significant difference between the panels' evaluation in relation to the subsets S1, S2, S3 and S5 (Table $2)$. In the case of subset S4, the P-value indicated that there was no significant difference between the panels when the spaghetti samples were compared by control sample.

Furthermore, the differences between the panels in relation to selected properties were tested by Roy's test. The obtained critical value $(p<0.100)$ have shown the existence of significant differences for all properties within the subsets S1, S2, S3 and S5 (Table 3). As for the subset S4 the obtained critical value was $p>0.100$, no significant difference between the panels in relation to the assessment of chewiness, stickiness and overall quality was noticed. The critical $p$-value $(p<0.100)$ obtained for the assessment of firmness and adhesiveness indicated that significant differences between the panels for the observed properties of cooked spaghetti samples existed.

This study showed that the utilization of consumer based measurements is not sometimes recommended as an equivalent to the experts whereas Moskowitz (1996) concluded that both groups are able to show similar types of results on similar attributes on the basis of the comparison of the results from expert and untrained panelists. Also, Worch et al. (2010) showed high similarity between the expert and consumer panels by comparing panels' performance using the confidence ellipses methodology. 
Table 2.

The significance of differences between the panels in relation to the observed subsets (MANOVA)

\begin{tabular}{ccc}
\hline Subset & $\mathbf{F}$ & $\mathbf{P}^{\mathbf{a}}$ \\
\hline S1 & 19.590 & 0.000 \\
S2 & 6.304 & 0.000 \\
S3 & 18.901 & 0.000 \\
S4 & 0.818 & 0.540 \\
S5 & 9.434 & 0.003 \\
\hline${ }^{a} p \leq 0.05$ & &
\end{tabular}

Table 3.

The significance of differences between the properties within the subsets

\begin{tabular}{cccccc}
\hline Subset & Property & $\chi^{\mathbf{a}}$ & $\mathbf{R}^{\mathbf{b}}$ & $\mathbf{F}^{\mathbf{c}}$ & $\mathbf{P}$ \\
\hline \multirow{4}{*}{ S1 } & Shape & 0.308 & 0.324 & 25.946 & 0.000 \\
& Surface appearance & 0.353 & 0.377 & 36.696 & 0.000 \\
& Cross-section apperance & 0.221 & 0.226 & 11.916 & 0.001 \\
& Surface property & 0.229 & 0.235 & 12.917 & 0.001 \\
& Fracturability & 0.350 & 0.374 & 35.990 & 0.000 \\
S2 & Surface appearance & 0.185 & 0.189 & 8.154 & 0.005 \\
& Surface adhesiveness & 0.203 & 0.207 & 9.910 & 0.002 \\
& Elasticity & 0.166 & 0.169 & 6.483 & 0.011 \\
& Firmness & 0.246 & 0.253 & 15.175 & 0.000 \\
S3 & Chewiness & 0.235 & 0.241 & 13.686 & 0.000 \\
& Adhesiveness & 0.235 & 0.242 & 13.728 & 0.000 \\
& Firmness & 0.198 & 0.202 & 9.391 & 0.003 \\
& Chewiness & 0.206 & 0.210 & 10.211 & 0.002 \\
S4 & Adhesiveness & 0.349 & 0.373 & 35.651 & 0.000 \\
& Surface adhesiveness & 0.273 & 0.284 & 19.421 & 0.000 \\
& Firmness & 0.122 & 0.123 & 3.418 & 0.062 \\
S5 & Chewiness & 0.090 & 0.091 & 1.846 & 0.172 \\
& Adhesiveness & 0.116 & 0.116 & 3.059 & 0.078 \\
& Sticky & 0.079 & 0.079 & 1.412 & 0.234 \\
& Overall quality (vs. control sample) & 0.041 & 0.041 & 0.372 & 0.550 \\
& Overall quality & 0.197 & 0.201 & 9.350 & 0.003 \\
\hline
\end{tabular}

a $\chi$-Pearson's contingency coefficient $(P \leq 0.01)$

${ }^{\mathrm{b}} \mathrm{R}$ - Multiple regression coefficients

${ }^{\mathrm{c}} \mathrm{F}$ - value (Roy's test)

Table 4.

The coefficients of discrimination between the panels in relation to the properties

\begin{tabular}{ccc}
\hline Subset & Property & DC $^{\mathrm{a}}$ \\
\hline \multirow{3}{*}{ S1 } & Shape & $\mathbf{0 . 1 8 3 ^ { \mathrm { b } }}$ \\
& Fracturability & $\mathbf{0 . 0 7 6}$ \\
& Surface appearance & $\mathbf{0 . 0 5 9}$ \\
& Cros-section appearance & 0.018 \\
& Surface property & 0.012 \\
S2 & Surface adhesiveness & $\mathbf{0 . 0 6 3}$ \\
& Adhesiveness & $\mathbf{0 . 0 2 1}$ \\
& Surface appearance & $\mathbf{0 . 0 1 3}$ \\
& Elasticity & 0.006 \\
S3 & Firmness & 0.003 \\
& Chewiness & 0.002 \\
& Adhesiveness & $\mathbf{0 . 1 5 1}$ \\
S5 & Chewiness & $\mathbf{0 . 1 1 4}$ \\
& Surface adhesiveness & $\mathbf{0 . 0 2 4}$ \\
\hline
\end{tabular}

${ }^{a} \mathrm{DC}$ - discrimination coefficient

${ }^{\mathrm{b}}$ Bold values are statistically significant $(p \leq 0.05)$ 
Table 5.

Mahalanobis' distance between the panels and the contribution of the subset to the panel performance

\begin{tabular}{cccc}
\hline Subset & Panel 1 & Panel 2 & Contribution, \% \\
\hline S1 & 0.00 & 1.41 & 35.604 \\
& 1.41 & 0.00 & 31.239 \\
S3 & 0.00 & 1.24 & \\
& 1.24 & 0.00 & 22.205 \\
S2 & 0.00 & 0.88 & 10.951 \\
S5 & 0.88 & 0.00 & 0.000 \\
S4 & 0.00 & 0.43 & 0.00 \\
\hline
\end{tabular}

In the evaluation of the degree of similarity between the samples and the control one, the performance of untrained panel does not differ from the performance of a trained expert panel. Untrained panellists can describe the products in a reliable and repeatable way and do not differ from the trained experts. This observation leads to the conclusion that when no cognitive skills are needed the performance of trained and untrained subjects is similar, which was mentioned by González et al. (2001). In this particular case, the use of untrained panel appears to be a good alternative to the trained panel (Worch et al., 2010).

The $\mathrm{p}$-value of $\chi^{2}$ - test with the confidence intervals of $\chi$ without zero point indicated either weak or no relationship between the properties within subsets and the panels (Table 3).

By integration of the properties within each subset there were the significant differences between the panels, as well as the clearly defined boundaries between them in relation to the evaluated properties $(p<0.001)$ except for the $S 4 \quad(p>0.1)$. Hence, the S4 was excluded from the further observation.

The results of discriminative analysis are shown in Table 4. The most significant difference between the panels within the $S 1$ was recorded for the shape of dry spaghetti evaluated by the scoring method. Also, the significant differences were observed for the fracturability and surface appearance. Within the S2, the most significant differences between the panels were recorded for the surface adhesiveness, adhesiveness and surface appea- rance of cooked spaghetti evaluated by the scoring method. The adhesiveness, chewiness and surface adhesiveness of cooked spaghetti evaluated by the scale method (S3) were the most discriminative properties between the panels (Table 4). The coefficient of discrimination revealed the existence of significant differences between the panels in rating the overall quality of spaghetti when the hedonic scale method was applied.

From the calculated Mahalanobis distance, the existence of the biggest differences between the panels in relation to subsets $\mathrm{S} 1$ and $\mathrm{S} 3$, the moderate differences in relation to $\mathrm{S} 2$ and $\mathrm{S} 5$ and the minimum differences for the subset S4 was confirmed (Table 5).

The obtained results confirmed that S1 $(35.604 \%)$ and S3 (31.239\%) gave the greatest contribution to the performances of the panels. For this reason, this study should be considered comprehensively with all subsets according to their sequence (Table 5).

Accordingly, the biggest differences in the performances of the panel were obtained when the samples of spaghetti had been evaluated using the scoring method and scale. At the same time, the biggest difference in assessment was obtained for shape of S1 (52.59\%), adhesiveness of S3 $(58.33 \%)$ and surface adhesiveness of S2 (58.33\%).

It might be that the untrained and trained panel differ because the trained panel has been taught to recognize nuances in these properties such as adhesiveness and surface adhesiveness whereas the untrained have not. Also, this might be due to the 


\section{Table 6.}

The performances of the panel and the contribution of the property to the panel performance by subsets

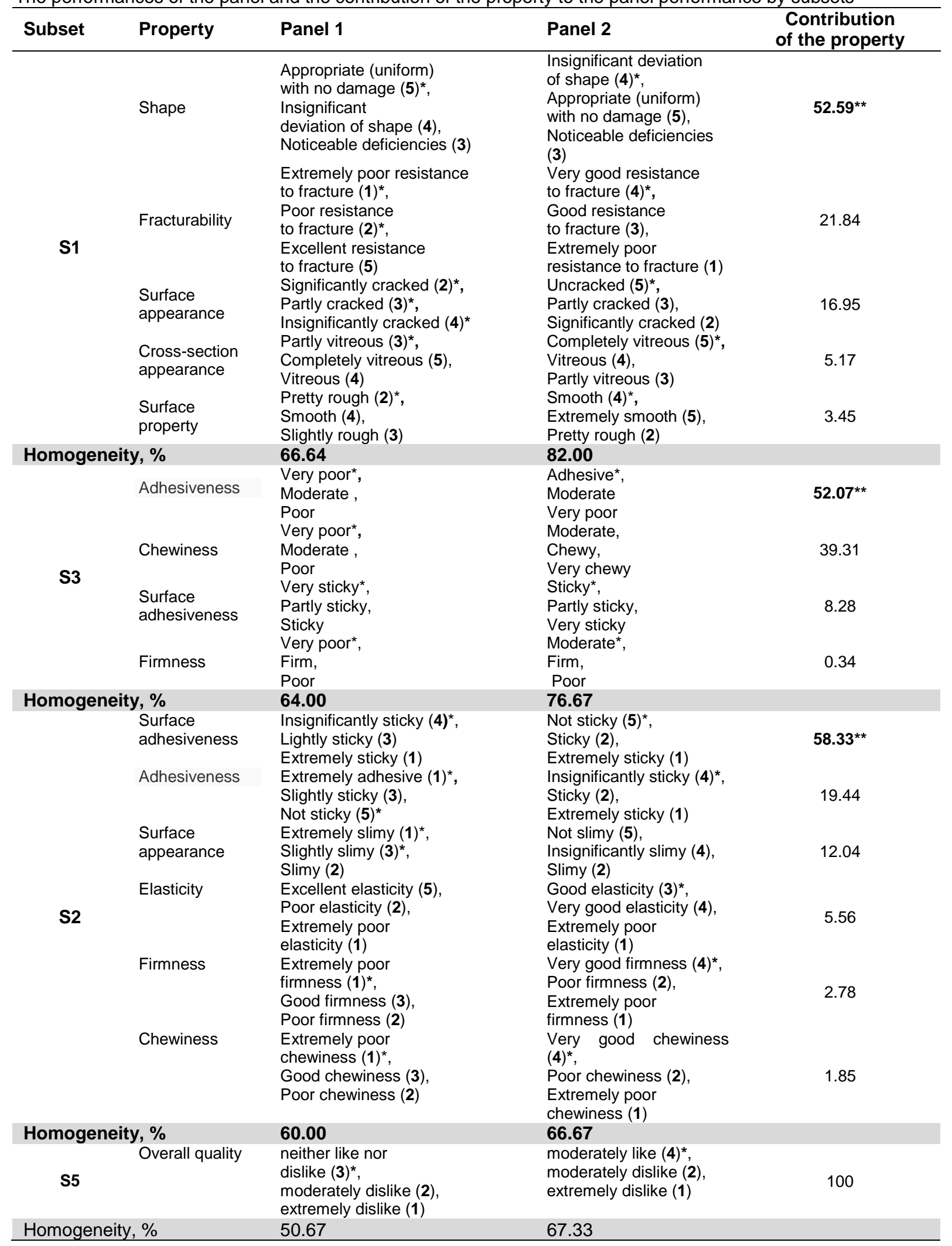

* Bold values are statistically significant $(p \leq 0.05)$

** Bold values indicate a contribution of a specific property of evaluated quality 
As Panel 2 showed higher percent of homogeneity across all sections in relation to the Panel 1, it can be concluded that the pasta samples were more frequently evaluated by higher assessments by Panel 2 in comparison to Panel 1 (Table 6). It is also worth mentioning, that trained panellists are able to extract specific features or attributes from the total percept in order to make overall assessment, unlike the untrained panellist who assess the overall quality on the basis of liking at the moment of assessment.

\section{CONCLUSIONS}

In general, the performed experiments demonstrated that the trained and untrained panel assessments differ quantitatively due to better increased discriminative ability of the trained panellists and due to the lack of training of untrained panellists. On the basis of the obtained results it can be concluded that clear differences between the trained and untrained panel are obvious except in the case when the properties of spaghetti were evaluated using the control sample.

\section{ACKNOWLEDGEMENTS}

This work was financed by the Ministry of Education and Science, Republic of Serbia (Project No. III 46001).

\section{REFERENCES}

1. AACC (1995). Approved Methods of the American Association of Cereal Chemists $\left(9^{\text {th }}\right.$ ed.) Methods 16-50. The Association, St. Paul, USA.

2. Cardello, A., Maller, O., Kapsalis, J.G., Segars, R.A., Sawyer, F.M., Murphy, C., Moskowitz, H.R. (1982). Perception of texture by trained and consumer panelists. Journal of Food Science, 47, 1186-1197.

3. Civille, G.V., Szczesniak, A.S. (1973). Guidelines to training a texture profile panel. Journal of Sensory Study, 4, 204-230.

4. Cole, M.E. (1991). Review: Prediction and measurement of pasta quality. International Journal of Food Science and Technology, 26, 133-151.

5. D’Egidio, M.G., Nardi, S. (1996). Textural measurements of cooked spaghetti. In Pasta and Noodle Technology. Eds. J. E. Kruger, R. R. Matsuo., J. W. Dick, , American Association of Cereal Chemistry Inc., St Paul, USA, pp. 133-156.
6. Gonzáles, R., Benedito, J., Cárcel, J.A., Mulet, A. (2001). Cheese hardness assessment by experts and untrained judges. Journal of Sensory Studies, 16, 277-285.

7. Guerrero, L., Gou, P., Arnau, J. (1997). Descriptive analysis of toasted almonds: a comparison between experts and semi trained assessors. Journal of Sensory Studies, 12, 39-54.

8. Hough, G.T. (1998). Expert versus consumers: A critique. Journal of Sensory Studies, 13, 285289.

9. ISO (International Organization for Standardization) ISO 11036 (1994). Sensory Analysis. Methodology. Texture profile. ISO, Geneva, Switzerland.

10. ISO (International Organization for Standardization) ISO 7340 (1985). Durum wheat semolina and alimentary pasta. Estimation of cooking quality of spaghetti by sensory analysis. ISO, Geneva, Switzerland.

11. ISO (International Organization for Standardization) ISO 8586-2 (1994). Sensory analysis. General guidance for the selection, training and monitoring of assessors. Part 2. Experts. ISO, Geneva, Switzerland.

12. Kovacs, M.I.P., Poste, L.M., Butler, G., Woods, S. M., Leisle, D., Noll, J.S., Dahlke, G. (1997). Durum wheat quality: Comparison of chemical and rheological screening test with sensory analysis. Journal of Cereal Science, 25, 65-75.

13. Latreille, J., Mauger, E., Ambrosine, L., Tenenhaus, M., Vincent, M., Navarro, S., Guinot, C. (2005). Measurement of the reliability of sensory panel performance. Food Quality and Preference, 17, 369-375.

14. Lee, S. J., Rha, M., Koh, W., Park, W., Lee, C., Kwon, Y.A., Hwang, J.K. (2002). Measurement of cooked noodle stickiness using a modified instrumental method. Cereal Chemistry, 79, 838-842.

15. Malcomson, L.J. (1991). Spaghetti optimization using response surface methodology: Effect of drying temperature, durum protein level and farina blending, $P h D$ Thesis, University of Manitoba, Winnipeg, Canada.

16. Martinez, C.S., Ribotta, P.D., León, A.E., Añón, M.C. (2007). Physical, sensory and chemical evaluation of cooked spaghetti. Journal of Texture Studies, 38, 666-683.

17. Menger, A. (1985). Entwicklung eines 5-punkteprueschemas zur sensorischen Beurteilung von Teigwaren. Getreide Mehl und Brot, 39, 61-65.

18. Moskowitz, R.H. (1996). Experts versus consumers: A comparison. Journal of Sensory Studies, 11, 19-37.

19. Muñoz, A.M. (1985). Development and application of texture reference scales. Journal of Sensory Studies, 1, 55-83.

20. Pestorić, M., Pojić, M., Sakač, M., Mastilović, J., Šimurina, O., Filipčev, B., Živančev, J. (2012). Selection of optimal sensory properties for the recognition of wholemeal bread. International Journal of Food Properties, 15 (4), 748-757. 
21. Popper, R., Risvik, E., Martens, H., Martens, M. (1988). A comparison of multivariate approaches to sensory analysis and the prediction of acceptability. In Food Acceptability. Ed. D. M. $\mathrm{H}$. Thomson, Elsevier Science Publishers, London, UK, pp. 401-410.

22. Sissons, M.J., Egan, N.E., Gianibelli, M.C. (2005). New insights the role of gluten of durum pasta quality using reconstitution method. Cereal Chemistry, 82, 601-608.

23. Sözer, N., Dalgic, A. C., Kaya, A. (2007). Thermal, textural and cooking properties of spaghetti enriched with resistant starch. Journal of Food Engineering, 81, 476-484.

24. Sözer, N., Kaya, A. (2003). Changes in cooking and textural properties of spaghetti cooked with different levels of salt in the cooking water. Journal of Texture Studies, 34, 381-390.

25. Stone, H., Sidel, L. (1998). Quantitative descriptive analysis: Developments, applications and the future. Food Technology, 52, 48-52.

26. Szczesniak, A.S. (1963). Classification of textural characteristics. Journal of Food Science, 28, 385-389.

27. Szczesniak, A.S. (1998). Sensory texture profiling. Historical and scientific perspectives. Food Technology, 52, 54-57.
28. Szczesniak, A.S. (2002). Texture is a sensory property. Food Quality and Preference, 13, 215-225.

29. Tang, C., Hsieh, F., Heyman, H., Huff, H. E. (1999). Analyzing and correlation instrumental and sensory data: A multivariate study of physical properties of cooked wheat noodles. Food Quality and Preference, 22, 193-211.

30. Voisey, P. W., Wasik, R. J., Loughheed, T.C. (1978a). Measuring the texture of cooked spaghetti, 1. Sensory and instrumental evaluation of firmness. Canadian International Food Science and Technology Journal, 11, 142-148.

31. Voisey, P. W., Wasik, R. J., Loughheed, T.C. (1978b). Measuring the texture of cooked spaghetti 2: Exploratory work on instrumental assessment of stickiness and its relationship to microstructure. Canadian International Food Science and Technology Journal, 11, 180-188.

32. Wilbur, A.T. (1984). An Introduction to Multivariate Statistical Analysis. John Wiley \& Sons, New York-Chichester-Brisbane-Toronto-Singapore.

33. Worch, T., Lê, S., Punter. P. (2010). How reliable are the consumers? Comparison of sensory profiles from consumers and experts. Food Quality and Preference, 21, 309-318.

\title{
СЕНЗОРСКА ДИФЕРЕНЦИЈАЦИЈА КОМЕРЦИЈАЛНО ПРОИЗВЕДЕНИХ ШПАГЕТА
}

\author{
Младенка В. Песторић¹, Милица М. Појић ${ }^{1}$, Бојана В. Филипчев ${ }^{1}$, Оливера Д. \\ Шимурина ${ }^{1}$, Александра М. Торбица ${ }^{1}$, Елизабет ${ }^{1}$ П. Јанић Хајнал \\ ${ }^{1}$ Универзитет у Новом Саду, Научни институт за прехрамбене технологије у Новом Саду, \\ 21000 Нови Сад, Булевар цара Лазара бр. 1, Србија
}

Сажетак: Овај рад је био фокусиран на учинак рада утренираног и неутренираног панела у оцени текстуре девет комерцијалних узорака пшеничних шпагета. Неколико сензорских метода било је примењено у циљу испитивања учинка различитих панел група. Да би се избегао губитак информација добијених од стране непараметарских метода, подацима су придодате вредности у складу са табелама контигенције. Ова анализа је показала да постоје значајне разлике у оцени између два панела за одређене производе. На основу ових резултата, може се закључити да примењени панели не могу бити добра алтернатива једни другима, да би се обезбедило сензорско профилисање текстуре комерцијалних шпагета, осим у случају када су својства шпагета оцењена уз примену контролног узорка.

Кључне речи: сензорска оцена, тестенина, текстура, потрошачка прихватљивост, поређење панела

Received: 16 September 2015

Accepted: 17 November 2015 